\title{
Education Continuation Strategies during COVID-19 in Malaysia
}

Nurul Ashikin Izhar, Yahya M. Al-Dheleai and Nor Asniza Ishak

To Link this Article: http://dx.doi.org/10.6007/IJARBSS/v11-i4/9840

DOI:10.6007/IJARBSS/v11-i4/9840

Received: 06 February 2021, Revised: 12 March 2021, Accepted: 10 April 2021

Published Online: 27 April 2021

In-Text Citation: (Izhar et al., 2021)

To Cite this Article: Izhar, N. A., Al-Dheleai, Y. M., \& Ishak, N. A. (2021). Education Continuation Strategies during COVID-19 in Malaysia. International Journal of Academic Research in Business and Social Sciences, 11(4), 1423-1436.

\section{Copyright: (c) 2021 The Author(s)}

Published by Human Resource Management Academic Research Society (www.hrmars.com)

This article is published under the Creative Commons Attribution (CC BY 4.0) license. Anyone may reproduce, distribute, translate and create derivative works of this article (for both commercial and non-commercial purposes), subject to full attribution to the original publication and authors. The full terms of this license may be seen at: http://creativecommons.org/licences/by/4.0/legalcode

Vol. 11, No. 4, 2021, Pg. 1423 - 1436

Full Terms \& Conditions of access and use can be found at http://hrmars.com/index.php/pages/detail/publication-ethics 


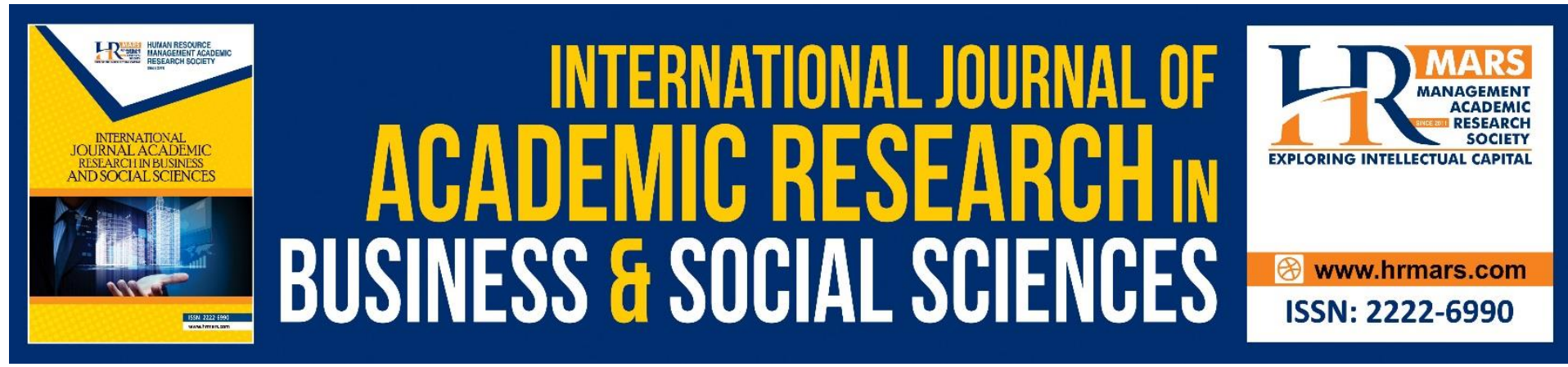

\title{
Education Continuation Strategies during COVID- 19 in Malaysia
}

\author{
Nurul Ashikin Izhar, Yahya M. Al-Dheleai and Nor Asniza Ishak \\ School of Educational Studies, Universiti Sains Malaysia, 11800 USM, Pulau Pinang, \\ Malaysia \\ Email: shikinizhar@gmail.com, yamohd3@gmail.com, asnizaishak@usm.my
}

\begin{abstract}
COVID-19 pandemic causes Malaysia to make an early decision of a Movement Control Order (MCO) to control the spread of the virus. The purpose of this study is to look on to the education continuation strategies that implemented by the Malaysian Ministry of Education (MoE) during schools' closure as a measure to control the spread of COVID-19. This article reviewed the measures and the implemented strategies that taken by the MoE to ensure the delivery of learning to all public schools' students in the country. The review revealed that, the MoE introduced four strategies to be implemented during COVID-19, which are (1) flexible class schedule and pedagogies, (2) synchronous and asynchronous online class, (3) collaboration with mass media, and (4) digital learning communities for professional development. The implemented strategies enabled the education system to overcome the school's sudden closing issue and deliver the necessary education to students during the pandemic.
\end{abstract}

Keywords: COVID-19, Emergencies Remote Teaching, Online Teaching/Learning, Pandemic, Teaching/Learning Strategies, School Closure, Education Continuation

\section{Introduction}

The outbreak of COVID-19 affected the world population health, economy and social life. COVID-19 is a disease that causes respiratory infections. A healthy person could be infected with inhaling tiny droplets of an infected person once they cough, sneeze, speaks, or touching the surfaces of the object in which the droplets landed (World Health Organization [WHO], 2020a). On the alarming spreading and severity of the infections, World Health Organizations (WHO) have declared the COVID-19 as pandemic to the world on March 11, 2020, and called for immediate social distancing measures and maintaining personal hygiene to prevent the spreading (WHO, 2020b).

To break the chain of the virus spread, most education institutions across the globe have taken the initiative to discontinue in-school teaching and learning (Dhawan, 2020). Until October 2020, countries such as Mexico, Ecuador, Argentina, Chile, Bolivia, Paraguay, Brazil, Guyana, Suriname, Mozambique, South Sudan, Uganda, Ethiopia, Somalia, Saudi Arabia, Iraq, India, Myanmar, and Cambodia still implementing the school closure caused by COVID-19 (United Nations Educational, Scientific and Cultural Organization [UNESCO], 2020a). Taking 
the same approaches, on March 18 2020, the Malaysian government has instructed all of the educational institutions to be closed until further notice (National Security Council, 2020). Therefore, the current physical pedagogy approach had now entirely shifted into online teaching and learning due to education institutions (Dhawan, 2020). Hence, the swift action to shift into distance learning was taken in a few days after the announcement on the severity of the infection made by WHO. The closure of educational institutions disrupts the learning opportunities among the students (Dhawan, 2020). Therefore, the action of education institutions closure has effected about 1.58 billion students worldwide ranging from preschool to higher education at around 200 countries (United Nations, 2020). Consequently, the action in mitigating the class continuation through online learning has seen to occur in China, Italy, France, Germany, and also Saudi Arabia (Azzi-Huck \& Shmis, 2020).

However, the vulnerable groups' students who did not have access to proper technology infrastructure such as possing gadgets with an internet connection, may lose the learning opportunities which they can have previously at school. Besides, the learning opportunities also be threatened by students who were having unconducive home environment (United Nations, 2020). Hence, to overcome the mentioned concerns, education authority needs to develop various strategies to ensure education delivery to as many learners as possible.

In the situation, the Malaysia government has taken the initiative to ensure the continuation of schooling via online education to overcome class disruptions. During the pandemic crisis, school closure has taken effectively to all schools for entire Malaysia. This sudden closure is a mechanism to prevent the spreading of the virus (Zhang et al., 2020). Thus, the MoE decided to use online learning platforms to continue lesson delivery to replace physical schools (Ministry of Education [MOE], 2020a). Fortunately, 90.1\% and $91.0 \%$ of Malaysia's households have access to the internet and smartphones, respectively (Department of Statistics Malaysia, 2020). Thus, taking into consideration these opportunities, class continuation by relying on the internet connection seems to be the best measure available.

The phenomenon of a sudden shift to full online teaching and learning required teachers and students to adapt to new situations. In regular schooling, there is a lack of realistic implementation scenarios for massive-scale online education. Regularly, students go to schools to engage in conventional classroom teaching for class teaching and learning. As before, online materials and technology were used as teaching aids in enhancing content delivery (Chen, 2008), while now, all activities occur via online tools (Zhou et al., 2020).

For a more in-depth look at what has been done, this article focuses on Malaysian practice for learning continuation during school closing. This paper contains five main sections. Section 2 briefly described the levering technology plan for education in Malaysia. In section 3 is reviewed on the recommended strategies for education continuation during the pandemic. Section 4 relates to the implementation of education continuation strategies in Malaysia. Lastly, sections 5 and 6 conclude with the discussion related to the recommended strategies and the implemented strategies.

\section{Schools Technology Scale-Up Plan in Malaysia}

Harnessing the power of ICT for education in Malaysia has its history a few years back. The Smart School project, which established in 1997 containing 88 pilot schools, is an example of Malaysian government efforts to integrate technology in education. The program provided 88 schools with advanced ICT infrastructure and facilities. The equipment facilities include broadband, network facilities, and educational TV programs. Moreover, teachers are 
provided with training on using ICT and the best practice of integrating technology in teaching their curriculum. The integration of ICT in Smart schools involves four major waves which are; (1) The Pilot (1999-2002), (2) The Post Pilot (2002-2005), (3) Making all Schools Smart (20052010), and (4) Consolidate and Stabilise (2010-2020) (Garba et al., 2015). Over the years, the schools in Malaysia are equipped with three technological approaches; (1) necessary ICT infrastructure, (2) basic training of computer and internet usage, and (3) Learning Management System (LMS) (Garba et al., 2015).

As technology develops rapidly, leveraging technology to scale up learning quality in Malaysia is then become one of the key elements devised in Education Blueprint 2013-2025. The scale-up was ranging from; (1) preparing students to learn within the digital world, (2) infrastructure upgrade, (3) teachers' training, (4) increasing student-to-device ratio, and (5) piloting ICT innovations (MOE, 2013). The agenda of Malaysia Education Blueprint 2013-2025 comprises of three waves; (1) Wave 1 focusing on enhancing the foundation such as infrastructure and competencies, (2) Wave 2 focused on ICT innovations such as EduWebTV, and (3) Wave 3 maintaining the innovative and broader usage in the curriculum (Table 1). To concludes, the approaches taken by MoE focuses on enhancing ICT have a long history in Malaysia. With the exposure, it is assumable that teachers and students are familiar in using technology in the teaching and learning process (MOE, 2013).

Therefore, the exposure to technology among teachers in Malaysia has improved their instructional strategies to facilitate their pedagogy and student-centred approaches over the year. VLE-Frog was then introduced as the LMS utilised by the public schools in Malaysia. Therefore students have started to be exposed to the online learning environment as teachers were adopting technology such as the prepared VLE-Frog in blended learning pedagogies. After a few years of trial implementation, the MoE has decided to shift the usage of LMS into Google Classroom starting July 1, 2019 (MOE, 2013; 2019).

Table 1: Three waves in leveraging ICT in education. Adapted from MOE (2013)

\begin{tabular}{|c|c|c|}
\hline Wave & Focus & Descriptions \\
\hline $\begin{array}{l}\text { Wave } 1 \\
(2013- \\
2015)\end{array}$ & $\begin{array}{l}\text { Enhancing } \\
\text { the } \\
\text { foundation }\end{array}$ & $\begin{array}{l}\text { Provide assess to the infrastructure for both teacher and } \\
\text { student. } \\
\text { Establishment of the Learning Management System (LMS) } \\
\text { with appropriate bandwidth } \\
\text { Teachers are ICT literate } \\
\text { Improving ICT programs monitoring mechanism } \\
\text { Integrating ICT into curriculum and management }\end{array}$ \\
\hline $\begin{array}{l}\text { Wave } 2 \\
(2016- \\
2020)\end{array}$ & $\begin{array}{l}\text { Introducing } \\
\text { ICT } \\
\text { innovations }\end{array}$ & $\begin{array}{l}\text { Transforming ICT usage in the classroom } \\
\text { Exploring ICT solutions for specific groups (under-enrolled, } \\
\text { rural schools, gifted students) } \\
\text { Reviewing best practices for the system by adopting } \\
\text { outcome-based assessment } \\
\text { Achieving a critical mass in ICT devices. }\end{array}$ \\
\hline $\begin{array}{l}\text { Wave } 3 \\
(2021- \\
2025)\end{array}$ & $\begin{array}{l}\text { Maintaining } \\
\text { innovative, } \\
\text { system-wide } \\
\text { usage }\end{array}$ & $\begin{array}{l}\text { ICT fully embedded in pedagogy and curriculum } \\
\text { Intense ICT usage among students and teachers. } \\
\text { Expanding the efforts on distance and self-paced learning and } \\
\text { curriculum }\end{array}$ \\
\hline
\end{tabular}




\section{Internationally Recommended Strategies for Education Continuation during the COVID-19 Pandemic}

United Nations Educational, Scientific, and Cultural Organization (UNESCO) have drawn education continuation strategies guidelines by considering the equity, inclusion, and learning quality. Developing an online learning strategy during the COVID-19 crisis is highly dependent on the immediate mitigation needs and long-term goal, guided with equity, inclusion, and quality of learning (UNESCO, 2020b). The strategies by UNESCO as in Table 2 based on experience and merging with the practical needs during the crisis.

Meanwhile, Organisations for Economic Co-operation and Development (OECD) have highlighted 25 responses class continuation during the pandemic of COVID-10 based on the assessment that is conducted in ninety-eight countries (Reimers \& Schleicher, 2020). Ensuring learning continuation, supporting students who lack independent study skills, and ensuring the wellbeing of students have been the address as the top three challenges mitigating the responses during the crisis. It may due to the availability of technological infrastructure, emotional health, availability of learning support at home, and willingness to adapt to the requires changes. Therefore, the strategies recommended by OECD look into establishing the task force in steering the situation focusing into the online education itself, support system towards school, teachers, students, and parents, communication plan, financial, and also social aspects such as social services and meals distribution.

Meanwhile, as the first country to experience total lockdown worldwide, China has implemented the 'Suspending classes without stopping learning' policy with five main elements. The policy focus on integrating national and local school teaching resources in supporting online education and supporting both teachers and students online learning. The policy tried to distinguish the difference in the learning process before and during the crisis. The policy also emphasises on the importance to deliver the content matter regarding epidemic prevention and control. Uniquely, the Chinese Ministry of Education also adapting continuous feedback regarding the implementation of policy and adjusting accordingly along the process (Zhang et al., 2020).

UNESCO, OECD, and China's education continuation strategies are presented in Table 2. In summary, the suggested guidelines based on UNESCO, OECD, and China education strategies were prepared in a way to reduce the disruptions, which may become severe learning losses to the students. 
Table 2: Education continuation strategies adopted by Zhang et al. (2020), Reimers and Schleicher (2020) and (UNESCO 2020b).

\begin{tabular}{|c|c|}
\hline Sources & Recommended strategies \\
\hline UNESCO & $\begin{array}{l}\text { - Manage online learning settings and supervision } \\
\text { - Adjusting assessment for monitoring the learning process } \\
\text { - Preparing teachers for pedagogical shifts and promoting collaboration } \\
\text { - Provide support for vulnerable students and families } \\
\text { - Boosting the learning management system platforms } \\
\text { - Alignment of online education resources with the national curriculum } \\
\text { - Adjusting curriculum goals and prioritise social aspect } \\
\text { - Examining the readiness and choose the most relevant technological solutions } \\
\text { - Increasing technological and content preparedness of online education } \\
\text { - Implement measures for all students to have access to online education } \\
\text { - } \text { opportunities } \\
\text { - Protecting the privacy and data security in cyberspace } \\
\text { - involvement of parents or caregivers. } \\
\text { - } \text { assessming lesson by blending student-centred teaching, monitoring, and } \\
\text { Planning the strategies to improved education with long-term goals }\end{array}$ \\
\hline OECD & 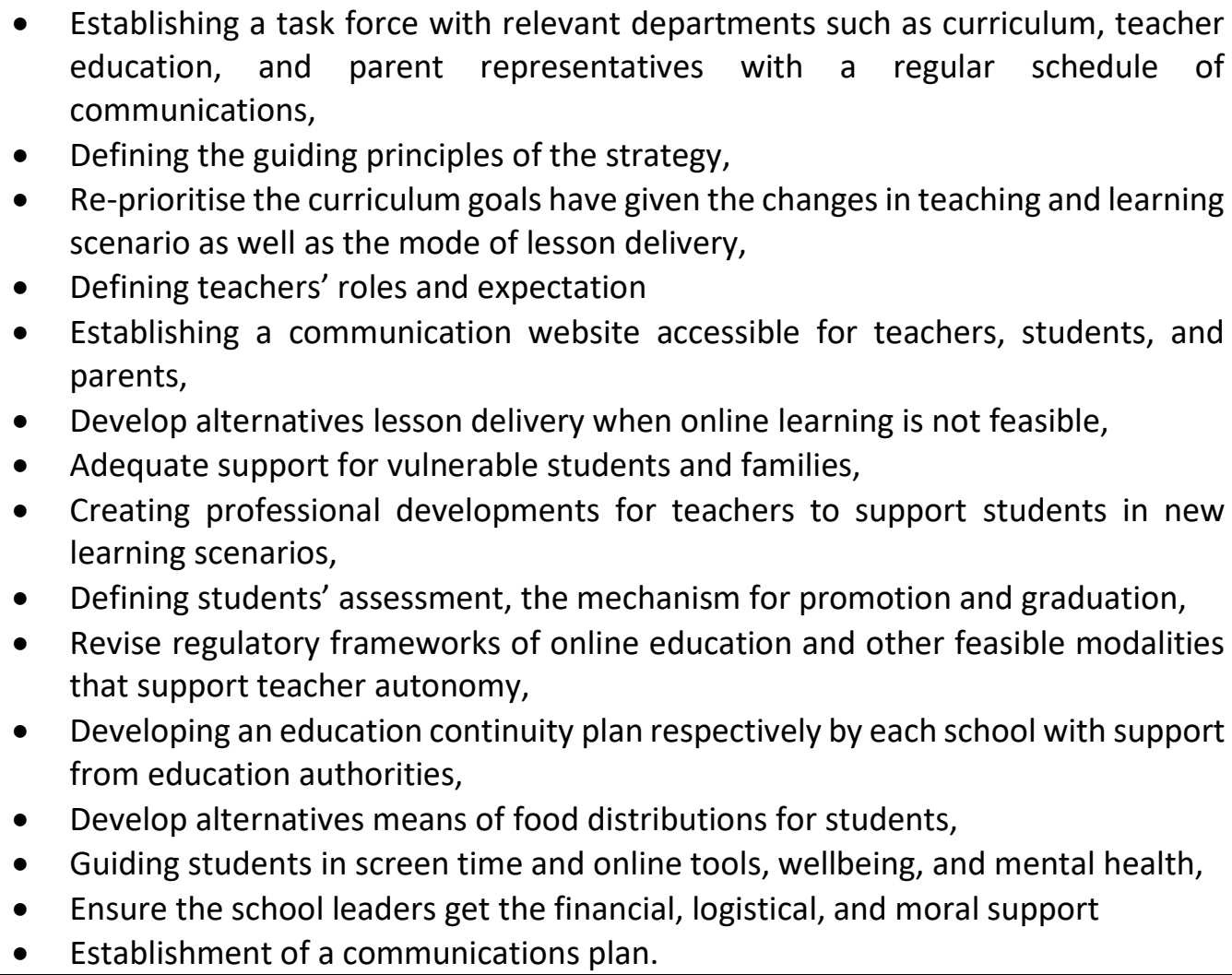 \\
\hline $\begin{array}{l}\text { Zhang et al. } \\
(2020)\end{array}$ & $\begin{array}{l}\text { - Integrating national resources into planning } \\
\text { - Providing training for teachers } \\
\text { - } \text { Autonomous for local authorities and schools to carry out online teaching } \\
\text { - } \text { depending on the local conditions } \\
\text { - Preparing guidelines for transitions for passed pandemic education } \\
\end{array}$ \\
\hline
\end{tabular}




\section{The Implemented Education Continuation Strategies during COVID-19 in Malaysia}

On the Malaysian government's MCO announcement, the MoE has enforced the school closure, with the class session taking place via online platforms (MOE, 2020a). The sudden shift from where previously a partial used of online learning platforms as teaching aids to the situation where all learning materials and activities are taken place on online learning platforms (MOE, 2020a).

In general, it is assumable that online teaching and learning are the best mechanisms in ensuring education during the unprecedented lockdown due to the COVID-19 pandemic (Reimers \& Schleicher, 2020; UNESCO 2020b; Zhang et al., 2020). Google Classroom was one of the most used as an online platform during the pandemic. It should be noted that each teacher and student in Malaysian public schools have their unique Google identification to be used to access their LMS, which is Google Classroom (MOE, 2019). Thus, these approaches have boosted the utilisation of Google Classroom as the primary LMS. The simplified and easy to use features available in Google Classroom have become the leverage used as the LMS. As a result, Malaysia was the top number one to use Google Classroom among 52 regions worldwide between March 18, 2020, to May 2, 2020, as shown in Figure 1 (Google Trends, 2020).

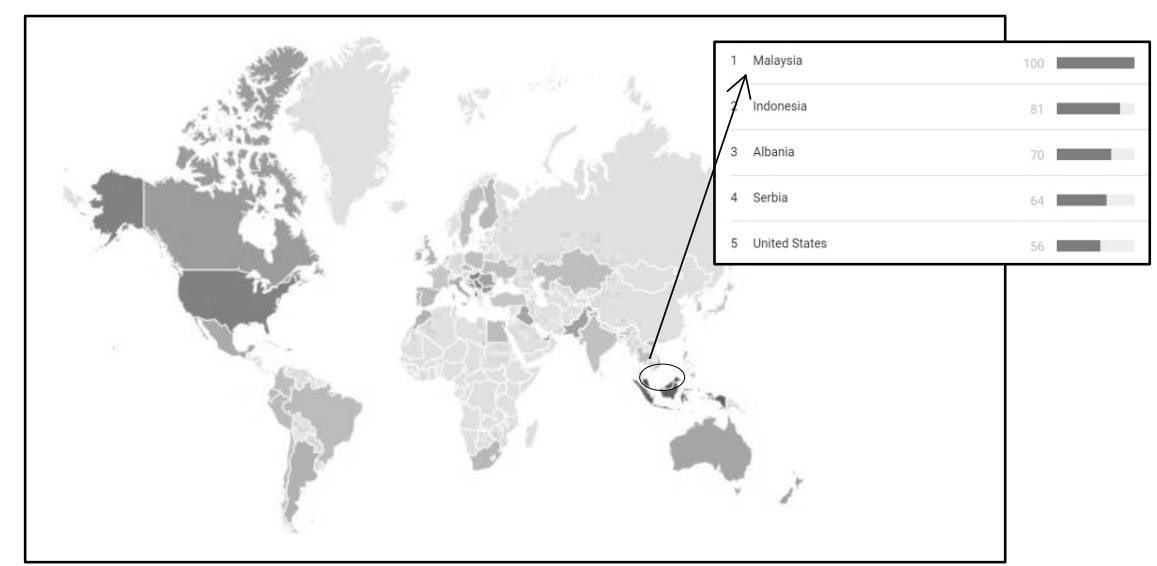

Fig. 1: Google Classroom Interest by Global Region (Google Trends, 2020).

To ensure the continuation of public schools' students learning, Education Ministry adopted four strategies to implement the best feasible plans for facilitating course delivery. The plans considered the technological capacity and accessibility, teachers' competencies, and students' ability to use the tool and involve parents in supporting their kids in their learning activities. The strategies outlined in the Ministry of Education's official website, press media, and other related documents are reviewed in the following section.

\section{Flexibility in Pedagogies}

The education ministry gave each school flexibility in deciding the appropriate class schedule, online class mechanism, checking students' tasks and assignments, and the learning assessment method. The flexibility strategies in continuing class sessions are considering staying at home with other external factors that may influence the effectiveness of the targeted lesson (Reimers \& Schleicher 2020; UNESCO, 2020b; Zhang et al., 2020). Teaching remotely from home may also be influenced by housework and its complex environment, which is different in teaching in the physical classroom (MOE, 2020a). Flexible schedules and pedagogy have a positive impact on the online teacher as it offers an opportunity for selfsatisfaction (Reimers \& Schleicher, 2020). 


\section{Synchronous and Asynchronous Lesson}

Synchronous interaction allows real-time communication between teachers and students while being in different places. For example, video conferencing allows teachers to conduct real-time lessons with students by being at their respective locations. Google Hangouts and Zoom are the standard video conferencing platforms that have been used by teachers in doing synchronous online teaching and learning. Besides, in overcoming online teaching and learning issues, teachers could also use any means of a medium such as social media platforms (Whatsapp, Telegram) in communicating with the students. The Ministry of Education has provided a platform that links to Google Classroom and Microsoft Team for online teaching and learning. Digital textbooks and YouTube channels referred to as EduwebTV and CikgooTube are among the prepared platforms supporting the learning materials (MOE, 2020a). Various online learning platforms can provide varieties of learning resources to be used by teachers and students (UNESCO, 2020b).

Meanwhile, asynchronous is when teachers provide the material on the platform, and students can access it at a convenient time. Google Classroom is the most common platform, as it is the official LMS platform used in Malaysia (MOE, 2019). Nevertheless, teachers can also provide offline learning activities using the textbook, workbooks, references book, or activities that are generally used in the classroom. The action of having Google Classroom and using the social media platform is in line with what recommendations in the OECD report suggested creating a medium of communication among teachers, students, and parents for the delivery of curriculum, activities, and learning resources (Reimers \& Schleicher 2020). Those mediums are crucial in enhancing remote teaching strategies during sudden school closure (UNESCO, 2020b). Additionally, teachers can also be creative by incorporating synchronous and asynchronous online teaching and learning to deliver their lessons.

\section{Involvement of Mass Media}

Despite the high percentage of Malaysia having access to technological gadgets, $36.9 \%$ of students in Malaysia do not have any electronic devices that be connected to the internet (Azman, 2020). It makes online teaching as a challenge to be employed during the school closure. In Malaysia, the rate of access to television is $97.6 \%$, which higher than to the internet (90.1\%) (Department of Statistics Malaysia, 2020). Thus, mass media have a role in implementing the initiatives to ensure the continuations of lessons. The neighbouring countries such as Vietnam and Mongolia have also taken advantage of using television as a mode for remote learning.

Meanwhile, in Bulgaria, two television channels were broadcasting educational programs to support school closure (Azzi-Huck \& Shmis, 2020). In Malaysia, the educational television program slots are conducted with the collaboration between the MOE and the Ministry of Communication. A program named Educational TV (TV Pendidikan) can be watched starting April 4, 2020, via TV Okey broadcasted by the Malaysia Radio Television (RTM) and the web streaming https://myklik.rtm.gov.my/. The extension is an initiative of the EduwebTV program (MOE, 2020b).

Therefore, students who have limited access to the internet could also watch the educational program via their television. Private television conglomerate, Astro Malaysia Holdings Bhd. (Astro) have collaborated with the MOE in broadcasting their education television program slot starting May 4, 2020, namely Tutor TV (MOE, 2020c). This program allows teachers and students to have broad online teaching and learning materials as Tutor TV and TV Okey are available as resources. The program's schedules are available on the 
Ministry of Education's official platform at www.moe.gov.my, Facebook, Instagram, and Twitter, (MOE, 2020b; 2020c).

The rate of households having televisions is higher than posing an internet connection. Thus, having an educational television program is a way to support the disadvantaged group (Department of Statistics Malaysia, 2020). Using mass media to reach the rural areas is parallel with OECD guidelines that highlighted television and radio program broadcast should be reinforced as a support resource to online education (Reimers \& Schleicher, 2020). Nevertheless, online learning using a television program can only be accessed with connections to the private television cable. Thus, it is challenging for students who have no access to television and devices with an internet connection.

\section{Online Teaching Support}

As online classes require a stable and fast internet connection; thus, a suitable bandwidth is essential for smooth delivery (Zhang et al., 2020). In China, few telcos have worked together to provide a fast and stable network to its citizen (Zhang et al., 2020). In Malaysia, YTL Foundations has taken the initiatives to provide free handphones with 12 months of $120 \mathrm{~GB}$ internet to students in need under the 'Learn from Home Initiatives' (YTL Foundations, 2020). Under the economic stimulus program, two initiatives in upgrading the internet connection have to be taken into action in Malaysia. Mobile telcos have distributed an extra 1GB free data daily from 8 am to $6 \mathrm{pm}$, starting April 1, 2020. Besides that, Telekom Malaysia and Time's telecommunications company has provided the additional fibre optic capacity in responding to serve stable internet connectivity (Yeoh, 2020).

Besides, the initiatives by Malaysia Ministry of Education, together with UNICEF Malaysia, has developed online resources and training to assist teachers in conducting online teaching and learning with Digital Learning Teachers Community with MOE in Figure 2 (MOE, 2020d). Five modules, as summarised in Table 3, were designed to facilitate teachers in preparing their online lessons and using Google Education products (MOE, 2020d). According to UNESCO (2020b), preparing teachers for pedagogical changes will contribute to the best potential integration of technology and pedagogy. Teacher's training program that just in time with the sudden school closure can foster support for both teachers and students (UNESCO, 2020b).

Table 3: Digital Learning Teachers Communities Modules in Collaboration between the Ministry of Education and UNICEF Malaysia. Adapted from MOE (2020d)

\begin{tabular}{l|l}
\hline Module & Descriptions \\
\hline Module 1: Let's start e-learning & $\begin{array}{l}\text { Teachers will explore MoE Digital Learning } \\
\text { platform, creating Google Classroom, and lesson } \\
\text { planning. }\end{array}$ \\
\hline $\begin{array}{l}\text { Module 2: Creating digital learning } \\
\text { material }\end{array}$ & $\begin{array}{l}\text { Creating materials using Google Docs, Google } \\
\text { Slides, and screen recording }\end{array}$ \\
\hline $\begin{array}{l}\text { Module 3: Interactive elements for } \\
\text { active learning }\end{array}$ & $\begin{array}{l}\text { Teachers will explore how to enhance interactive } \\
\text { elements to promote active learning }\end{array}$ \\
\hline $\begin{array}{l}\text { Module 4: Online assessments } \\
\text { Module 5: Positive digital } \\
\text { environment }\end{array}$ & $\begin{array}{l}\text { Teachers will explore how technology aids in } \\
\text { assessing students by Gradebook. }\end{array}$ \\
\hline $\begin{array}{l}\text { reating a positive digital environment, the } \\
\text { student between teacher-student, student- }\end{array}$
\end{tabular}




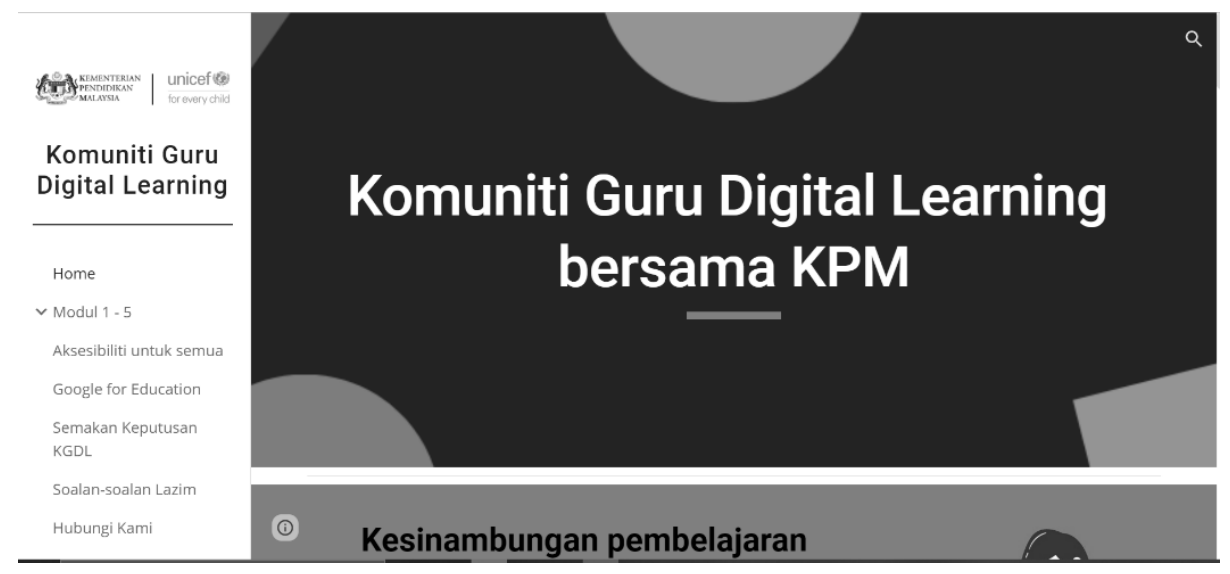

Fig. 2: Digital Learning Teachers Community (MOE, 2020d)

\section{Discussions}

This paper describes four instructional strategies adopted by the Education Ministry of Malaysia during the MCO due to the outbreak of COVID-19. Firstly, the pedagogies' flexibility is implemented as it is useful for the teachers' and students' online teaching and learning pace. Secondly, online teaching and learning lesson is tailored with synchronous and asynchronous approaches, supplemented with various learning materials. Third, as education is everyone's responsibility, the Ministry of Communication and the private sectors for creating educational television channels reflect the seriousness of the communities on education. While having online teaching support communities helps in providing imidate support to online teaching and learning.

The implementation of education continuation strategies has contributed to nonstopped education delivery during school closure. The implemented strategies have emphasised flexible class schedules and pedagogies, providing synchronous and asynchronous online teaching and learning, mass media involvement, and the digital learning communities for professional development. As the sudden school closure's first-time experience, it is expected to find some difficulties and limitations in the implemented strategies.

The implementation in Malaysia did not give enough considerations to the roles of parents or caretakers. In online education, teachers lose some direct control and supervision opportunities due to students and teachers being in two different places (MOE, 2020a). Thus, it is imperative to engaged parents in managing students' disciplines to reduce the disengagement between students and online classes, especially with students at the primary level (UNESCO, 2020b). Also, it is inaccurate to imply that students are technologically literate for academic functions as they are the digital natives. Students are highly using the technology for social aspects rather than to academic purposes (Malaysian Communications and Multimedia Commission [MCMC], 2018; Thang et al., 2016). Mishra et al. (2020) also highlighted that online learning during the crisis provide the feeling of discontent among students. The discontent may appear due to the facts that there is no longer human interaction between their teachers and peers, and the online learning environment itself. Besides, the disadvantages groups of students who cannot access both internets and learn through mass media are one of the main concerns that should be into planning for better improvement. The accessibility to the infrastructure such as internet connection and gadgets 
and home environment such as large families members in the small compound could influence students being group as the disadvantages. Therefore, it is suggested that for future research to take concern in the perspective of parents or caretakers, and students in mitigating a smooth online class session.

Besides that, monetary and award initiatives could also be considered a motivational booster for teachers to enhance and implement online education during the emergency period. Monetary and award initiatives are other alternatives to increase the active participation of teachers in conducting online education. Monetary initiatives have it influence on motivating teachers in utilising technology in the lesson. Besides, with the award initiatives, teachers will have believed that their effort is appreciated. Teachers who received the award could also be a reference point by other teachers as a role model in implementing digital learning in education.

The effort in establishing the online teaching support that provides immediate and easy to understand module such as Digital Learning Teachers Community is crucial in supporting teachers in shifting from the traditional class session into online education. Despite the support system that setup from the national level, it is recommended that the program in online education should also be available in the local school with the autonomous authority. The professional development program in a local school will increase teachers' collaboration, change ideas, and discussion at a more appropriate level, correspond with each school setting. Besides, teachers will have a near reference point in any case of ambiguity in using online education. Improving online teaching competencies among teachers and overcoming the technical and pedagogical challenges they faced during this experience is one way for a successful plan. Nevertheless, the successful implementation of online education during disruptions relies on all parties' efforts, such as teachers and students. Incompetent teachers, coupled with student's inactive engagement, would impede the implementation.

Getting the experience on the online education that was currently happening, it seems applicable to set up a team of digital teachers in each school with a representative from each department. A sudden change into online education needs a sudden comprehension of knowledge in using the technology in delivering the content with the appropriate pedagogy. Teaching using technology is not just a mere integration of technology into the lesson. Teaching using technology is a complex intervene of technological knowledge, pedagogical knowledge, content knowledge, technology-pedagogy knowledge, technology-content knowledge, pedagogy-content knowledge, and technology-pedagogy knowledge (Azzi-Huck \& Shmis, 2020). Thus, developing a digital learning community among teachers is crucial to provide support systems for their professional development. The designation of a team that consists of that from a various subject appears to be able to guide teachers in identifying the area that needed for consideration in planning technology-enabled lesson (Koh et al., 2017).

Besides, the researchers recommend a task force in facing the crisis represent different roles such as teacher representatives, parents representative, student representatives, industry representatives, curriculum department representative, and teacher professional development representative (Reimers \& Schleicher 2020). Implementing these strategies will contribute to better learning and easier access to learn with diverse perspectives to consider a wide range of area able to be covered such as the lesson design, communication medium, and support system. Besides, taking references on the mechanism by the Chinese Ministry of Education in continuously receiving feedback and making amendments that deem necessary is a way that may improve online education during the crisis. 
Looking into the infrastructure aspects, the initiatives taken by YTL Foundation are one of the out-of-the-box views of how private conglomerate able to contribute to reducing the discrepancies of online learning among the disadvantaged group. The government could make a new initiatives program that offered beneficial strategies to increase private conglomerate participation in supporting schools and students in the disadvantaged group (UNESCO, 2020b). A proper discussion could help such actions in reducing the cost of accessing internet access without affecting the connection stability and strength. The action of upgrading the mobile data coverage by the mobile telcos company and more fibre optic cable by the telecommunication providers are the initiatives that should be upgraded by time to time. If taking the example of video conferencing in the synchronous mode of lesson delivery, the action took a considerable amount of data coverage. Thus, ensuring cheap data coverage without disrupting the stability and strength is possibly in demand for effective online learning. The situation of MCO has led to some parents losing their job. Thus it will be another financial burden to be faced in providing mobile data to their kids if the cost is high. As facing the financial issues, it is also highly possible that there will be a disruption in online learning as financial will be more focus on survival during the crisis (Reimers \& Schleicher 2020). Meanwhile, looking into sensitive external variables such as home environments, it is critical to involve other authorities to join hand-in-hand to mitigate the situation.

\section{Conclusion and Recommendations}

The study investigated education continuation strategies faced during the sudden shift to online teaching and learning by focussing in Malaysia climate. The current study is useful to provide evidence-based data and recommendations to the Education Ministry on adopting online teaching mode or blended for public schools in Malaysia. In parallel with the severity of cases and high case and death tolls due to this pandemic, it can be assumed that online education may be the pedagogies strategies for a while. Thus individuals who are reluctant to changes, need now to accept the utilisation of cyberspace into education. The major query here is the online education able to provide the best quality in understanding the content, satisfaction, and the effect on the wellbeings and social growth for both teachers and students. Additionally, it is vital to support teachers in coping with a sudden shift from the traditional face-to-face classroom to full online teaching and learning through providing online resources and training.

According to the United Nations (2020), this ambiguity provides a needs for further exploration in 'preventing a learning crisis from becoming a generational catastrophe'. Ergo, current resarch provides varieties for oppurturnities for further research such as the impact for implementation strategies towards updated education program, effect of such implementation towards teachers professional development, students academic and mental development, the possibilities of emergent of digital learners, and the preparedness of every sector in education such as the school management, teachers, students, as well as parents towards not just only highlighting 21-st century learning skills, but also information, media, technology literacy skills. In order to instill the literacy skills among students, teachers should be occuipied with such skills first. However, education is not a one man show. Thus, parents involvement is essential to be look for in nowadays education. Moreover, investigating students' and parents' current knowledge would also help understand the applicability of adopting blended or online learning in the country. 


\section{Acknowledgements}

The authors would like to acknowledge Human Research Ethics Committee USM (HREC) for the ethical clearance for the study.

\section{References}

Azman, F. (2020). 36.9 per cent of pupils do not have electronic devices - Radzi Jidin. Astro Awani. http://english.astroawani.com/malaysia-news/36-9-cent-pupils-do-not-haveelectronic-devices-radzi-jidin-238505.

Azzi-Huck, K., \& Shmis, T. (2020, March 18). Managing the impact of COVID-19 on education systems around the world: How countries are preparing, coping, and planning for recovery. https://blogs.worldbank.org/education/managing-impact-covid-19education-systems-around-world-how-countries-are-preparing

Chen, C. H. (2008). Why do teachers not practice what they believe regarding technology integration? The Journal of Educational Research, 102(1), 65-75.

Department of Statistics Malaysia. (2020). ICT use and access by individuals and households survey report 2019.

https://www.dosm.gov.my/v1/index.php?r=column/pdfPrev\&id=SFRacTRUMEVRUFo1 Ulc4Y1JILzBqUT09.

Dhawan, S. (2020). Online learning: A panacea in the time of COVID-19 crisis. Journal of Educational Technology Systems, 49(1), 5-22.

Garba, S. A., Byabazaire, Y., \& Busthami, A. H. (2015). Toward the use of 21st century teachinglearning approaches: The trend of development in Malaysian schools within the context of Asia Pacific. International Journal of Emerging Technologies in Learning, 10(4), 72-79.

Google Trends. (2020, May 2). Google Classroom.

https://trends.google.com/trends/explore?date=2020-03-1820200502\&q=googleclassroom

Koh, J. H. L., Chai, C. S., \& Lim, W. Y. (2017). Teacher professional development for TPACK21CL: Effects on teacher ICT integration and student outcomes. Journal of Educational Computing Research, 55(2), 172-196.

Malaysian Communications and Multimedia Commission (MCMC). (2018). Internet users survey 2018. https://www.mcmc.gov.my/skmmgovmy/media/General/pdf/InternetUsers-Survey-2018.pdf

Ministry of Education (MOE). (2013). Malaysia Education Blueprint 2013-2025. https://www.moe.gov.my/menumedia/media-cetak/penerbitan/dasar/1207malaysia-education-blueprint-2013-2025/file

Ministry of Education (MOE). (2019). Google classroom. https://www.moe.gov.my/en/pemberitahuan/announcement/google-classroom-gc

Ministry of Education (MOE). (2020a). Media statement: Implementation of teaching \& learning during movement control order (Kenyataan media: Pelaksanaan pengajaran dan pembelajaran berikutan perlanjutan tempoh perintah kawalan pergerakan). https://www.moe.gov.my/pemberitahuan/kenyataan-media/kenyataan-mediapelaksanaan-pengajaran-dan-pembelajaran-berikutan-perlanjutan-tempoh-perintahkawalan-pergerakan.

Ministry of Education (MOE). (2020b). Media statement: Education TV program slot at TV OKEY channel, Malaysia Radio Television (Kenyataan media: Slot program TV pendidikan di saluran TV OKEY, Radio Televisyen Malaysia, RTM). https://www.moe.gov.my/pemberitahuan/kenyataan-media/kenyataan-media-slot- 
program-tv-pendidikan-di-saluran-tv-okey-radio-televisyen-malaysia-rtm

Ministry of Education (MOE). (2020c). Media statement: Educational TV program slots on Tutor TV Channel, Astro (Kenyataan media: Slot program TV pendidikan di saluran Tutor TV, Astro). https://www.moe.gov.my/pemberitahuan/kenyataan-media/kenyataanmedia-slot-program-tv-pendidikan-di-saluran-tutor-tv-astro

Ministry of Education (MOE). (2020d). Digital learning teacheres community with $\mathrm{MoE}$ (Komuniti guru digital learning bersama KPM). https://sites.google.com/moedl.edu.my/ldp-digital-learning/home?authuser=1

National Security Council. (2020). Media statement MKN: Details on the movement control order (Kenyataan media MKN: Perincian perintah kawalan pergerakan). https://www.pmo.gov.my/2020/03/kenyatan-media-mkn-18-mac-2020/

Reimers, F. M., \& Schleicher, A. (2020). A framework to guide an education response to the COVID-19 Pandemic of 2020. Organisation for Economic Co-operation and Development (OECD). 227-268.

Thang, S. M., Lee, K. W., Murugaiah, P., Jaafar, N. M., Tan, C. K., \& Bukhari, N. I. A. (2016). ICT tools patterns of use among Malaysian ESL undergraduates. GEMA Online Journal of Language Studies, 16(1), 49-65.

United Nations Educational, Scientific and Cultural Organization (UNESCO). (2020a). Education: From disruption to recovery.

https://en.unesco.org/covid19/educationresponse

United Nations Educational, Scientific and Cultural Organization (UNESCO). (2020b). UNESCO COVID-19 education response education sector issue. Notes: Distance learning strategies in response to COVID-19 school closures. https://unesdoc.unesco.org/ark:/48223/pf0000373305?posInSet=2\&;queryld=N8ea77989-29de-4ff3-997c-eaddc678be5b

United Nations. (2020). Policy brief: Education during COVID-19 and beyond. https://reliefweb.int/report/world/policy-brief-education-during-covid-19-andbeyond-august-2020.

World Health Organization (WHO). (2020a). Q\&A on Coronaviruses. https://www.who.int/emergencies/diseases/novel-coronavirus-2019/question-andanswers-hub/q-a-detail/q-a-coronaviruses

World Health Organization (WHO). (2020b). Timeline of WHO's response to COVID-19. https://www.who.int/news-room/detail/29-06-2020-covidtimeline

Yeoh, A. (2020). MCO: Telco's to offer free 1GB data daily from April 1, here's what you should know. The Star. https://www.thestar.com.my/tech/tech-news/2020/03/27/mcotelcos-to-offer-free-1gb-data-daily-from-april-1-here039s-what-you-should-know

YTL Foundations. (2020). YTL foundation asking teachers' help in distributing free smartphones (Yayasan YTL memohon bantuan guru bagi memberikan telefon pintar percuma). https://ytlfoundation.org/wp-content/uploads/2020/04/070420-YTLFPress-Release-BM.pdf

Zhang, W., Wang, Y., Yang, L., \& Wang, C. (2020). Suspending classes without stopping learning: China's education emergency management policy in the COVID-19 Outbreak. Journal of Risk and Financial Management, 13(3), 55.

Zhou, L., Wu, S., Zhou, M., \& Li, F. (2020). 'School's out, but class' on', the largest online education in the world today: Taking China's practical exploration during the COVID-19 epidemic prevention and control as an example. Best Evidence Chinese Education 4(2), 501-519. 